\title{
Helicobacter Pylori Infection / Hepatic Encephalopathy Inter- Relationship before and after its Eradication
}

\author{
Salama M. El Ghonaimy ${ }^{1}$, Sami E. Abd El-Wahab ${ }^{1}$, \\ Yosri E. Abo El Magd ${ }^{2}$, Sherweet M. Ibrahim ${ }^{1}$ \\ ${ }^{I}$ Tropical medicine Department,Faculty of Medicine, Zagazig University, Egypt. \\ ${ }^{2}$ Biochemistry Department,Faculty of Medicine, Zagazig University, Egypt.
}

Corresponding Author

Sherweet M. Ibrahim

E mail:

sherisahlol@yahoo.co $m$

Received:5/2 /2012

Accepted after

revision: $1 / 5 / 2012$

Key words:

Helicobacter Pylori;

Hepatic

encephalopathy;

Hyperammonemia.
Background and study aim: Helicobacter pylori (H. pylori) bacteria convert urea to ammonia, which has been implicated in causation of hepatic encephalopathy(HE) in patients with liver cirrhosis.The aim of this work was to assess the effect of helicobacter pylori infection and its eradication on hepatic encephalopathy.

Patients and methods: From March 2010 to November 2011, in Tropical Medicine Department, Zagazig university Hospitals, 90 patients with grade 0-II hepatic encephalopathy were enrolled in the study. The patients diagnosed for hepatic encephalopathy using psychometric tests [number connection test (NCT), and circle connection test( CCT)] and Grading of the symptoms of hepatic encephalopathy was performed, they were evaluated for $\mathrm{H}$. pylori infection (through detection of $\mathrm{H}$. pylori stool Ag), liver impairment, and blood ammonia concentration. A group of the H. pylori +ve patients were given eradication therapy (triple therapy: $1 \mathrm{wk}$ therapy with omeprazole plus clarithromycin and tinidazole), then patients were revaluated after 2 months using psychometric tests and blood ammonia concentration and compared with untreated group.

Results: In our study, the mean level of blood ammonia concentration was significantly higher in $\mathrm{H}$. pylori-positive patients (group II and III: 78.1 \pm 9.36 and $82.73 \pm 12.22 \mathrm{mmol} / \mathrm{L}$ ) in comparison to H. pylori-negative patients (group I: $65 \pm 17.47 \mathrm{mmol} / \mathrm{L}$ ) where $\mathrm{P}<0.001$. Also the time needed to perform NCT and CCT

\section{INTRODUCTION}

Hepatic encephalopathy is a spectrum of neuro-psychiatric abnormalities in patients with liver dysfunction [1]. Although the exact pathogenesis is unknown, accumulation of ammonia from poor hepatic function porto- show the lowest mean in $\mathrm{H}$. pylori negative patients $(64.73 \pm 13.08$ and $35.67 \pm 6.66$ sec. respectively) in comparison to $\mathrm{H}$. pylori- positive patients with statistically significant difference ( $\mathrm{P}<0.001$ for both tests). CCT was significantly reduced in treated and eradicated patients after therapy $(30.46 \pm 4.9 \mathrm{sec})$ and shows statistically significant difference $(\mathrm{P}<0.001)$ in comparison to untreated or failed to eradicate groups. The blood ammonia concentration in patients with $\mathrm{H}$ pylori was significantly reduced after bacterium eradication compared with the concentration after conventional treatment to $\mathrm{HE}$ in $\mathrm{H}$. pylori infected controls (49.04 \pm 13.67 vs $61.17 \pm 9.81)$. However, blood ammonia level was reduced in those who received treatment and failed to eradicate in a significant difference from those who didn't receive eradication therapy (infected controls) $(61.17 \pm 9.81 \mathrm{vs}$ $75 \pm 14.9$ ). Also there was statistically significant difference as regard to hepatic encephalopathy grade pre- and post treatment in infected treated and eradicated group $(\mathrm{P}=0.04)$ while there was no statistically significant difference in infected controls or failed to eradicate groups.

Conclusion: $\mathrm{H}$ pylori infection is an important factor for inducing high blood ammonia concentration in $\mathrm{HE}$ patients. Anti-H. pylori therapy results in reduction in blood ammonia levels and may be helpful for treatment and prevention of HE.

systemic shunting has been implicated as a primary factor [2]. Helicobacter pylori is a Gram -ve micro-aerophilic bacterium that inhabits stomach and duodenum [3]. Helicobacter pylori produces large amounts of the enzyme urease, molecules of which are 
localized inside and outside the bacterium. Urease breakdown urea to carbon dioxide and ammonia[4]. Elevated levels of ammonia could deteriorate hepatic encephalopathy. As a result, it can be posulated that helicobacter pylori infection may potentially contribute to the development of hepatic encephalopathy [5]. Helicobacter pylori eradication may be helpful for treatment and prevention of hepatic encephalopathy [6]. Other studies had showen ammonia levels do not significantly differ between cirrhotic patients with and without $\mathrm{H}$ pylori infection. Ammonia production in the stomach by $\mathrm{H}$ pylori urease appears to be inadequate to clinically affect ammonia disposal in the majority of cirrhotic patients [7-10].

\section{PATIENTS AND METHODS}

From March 2010 to November 2011, in Tropical Medicine Department, Zagazig University Hospitals; out of 145 examined hepatic encephalopathy patients at the start of the study, 90 educated patients with grade 0 -II hepatic encephalopathy were enrolled in the study. The patients diagnosed for hepatic encephalopathy using psychometric tests and grading of the symptoms of hepatic encephalopathy is performed according to the West Haven classification system [11] .All the studied patients were on similar therapy for hepatic encephalopathy with neomycin sulphate $500 \mathrm{mg}$ tab QID, oral lactulose at a dose level sufficient to assure two to three loose motions per day and protein restriction (about 40 gm per day) to reduce the effect of ammonia producing gut flora on hyperammonaemia. Exclusion criteria included patients who were illiterate, those with severe cardiac, pulmonary, cerebral, or renal disorders, patients with severe hepatic encephalopathy of grades III and IV, patients currently receiving helicobacter pylori eradication therapy, and patients with Active gastrointestinal bleeding.

The studied patients were grouped according to helicobacter pylori antigen in stool into 3 groups: Group I: (Non infected control group) H. pylori ve hepatic encephalopathy patient, Group II: (Infected group) H. pylori +ve hepatic encephalopathy patient who received eradication therapy (triple therapy omeprazole $20 \mathrm{mg}$ b.i.d plus clarithromycin $500 \mathrm{mg}$ b.i.d. plus tinidazole $500 \mathrm{mg}$ b.i.d for 1 week duration) and Group III: (Infected control group) H. pylori +ve hepatic encephalopathy patients who didn't receive eradication therapy.

Patients were evaluated by full history taking, thorough clinical examination for signs of chronic liver disease, and Psychometric tests [number connection test (NCT), circle connection test $(\mathrm{CCT})]$.

\section{Laboratory investigations}

Routine hematological and biochemical investigations which include liver function tests, kidney fuction tests, prothrombin time (PT), complete blood picture., $\mathrm{H}$ pylori infection by detection of $\mathrm{H}$. pylori $\mathrm{Ag}$ in stool, liver impairment (according to Child-Pugh classification, including the total score of HE, ascites, prothrombin time, albumin concentration and bilirubin level, which ranked as Child-Pugh class A, B and C), blood ammonia concentration, and HE grade were evaluated for all the patients.

\section{Detection of $\mathrm{H}$ pylori infection}

Enzyme-linked immunosorbent assay (ELISA) for $\mathrm{H}$. pylori $\mathrm{Ag}$ in stool have been done using anti-H. pylori antibodies coated on microwells to capture $\mathrm{H}$. pylori antigen and peroxidaseconjugated polyclonal antibodies to detect the immune complex. Fresh stool samples were collected from all the patients. This test was repeated for group II (infected group) to confirm eradication after 2 months of treatment.

\section{Ammonia measurement}

Fasting venous blood samples were obtained from each patient to measure ammonia concentration (mmol/L) and blood samples was collected in EDTA, according to the manufacturer's instructions.

\section{Psychometric tests}

All patients underwent NCT and CCT. Before the actual tests, the procedure was explained and demonstrated, and a dummy run was done, which was not taken into account. Time taken for completion of each test and the number of errors were recorded. The tests were repeated for groups II (infected treated group) and III (infected controls) after two months.

\section{$H$ pylori eradication therapy}

Group II patients with $\mathrm{H}$ pylori infection received 7 days triple eradication therapy (omeparazole $20 \mathrm{mg}$ b.i.d plus clarythromicin $500 \mathrm{mg}$ b.i.d plus tinidazole $500 \mathrm{mg}$ b.i.d.). 


\section{STATISTICAL ANALYSIS}

Statistics were calculated using SPSS ver. 10. Qualitative variables were expressed by means of frequency and percentiles, and were analyzed using the $\chi^{2}$ test. Quantitative results are expressed as means \pm SD. Groups were compared by using paired t test, ANOVA or the Wilcoxon signed-rank test.

\section{RESULTS}

In the present work, 90 educated patients with grade 0 -II hepatic encephalopathy diagnosed using psychometric tests (NCT and CCT) and gading of the symptoms of hepatic encephalopathy is performed. They were grouped depending on diagnosis of helicobacter pylori antigen in stool into 3 groups: non infected group (H. pylori negative), infected group who received treatment for $\mathrm{H}$. pylori eradication and infected group who didn't receive eradication therapy. Eradication rate in the group received eradication therapy was $80 \%(24 / 30)$.

There were no significant differences in Clinical and demographic characteristics between patients in the three groups of the study. Similarly the laboratory findings of patients in the three groups was not significantly different. Regarding ChildPugh class among studied groups (H. pylori positive and negative groups) in current study before treatment, there was no statistically significant difference where $\mathrm{P}$ were $0.160,0.950$, 0.563 for class A, B, C respectively. Also there was no statistically significant difference in regard to hepatic encephalopathy grade among different groups before treatment where $\mathrm{P}$ were $0.487,0.732,0.51$ in grades 0 , I, II respectively.

In this study, the frequency of precipitating factors of HE among different groups showed that infections (other than SBP) were the most frequent factor among all studied patients $(34.49 \%)$, followed by diuretics $(20 \%)$ and constipation was the least $(1.1 \%)$ with no statistically significant difference in all risk factors among studied groups.

In this study regarding the results of psychometric tests scores among studied groups before treatment, the time needed to perform NCT and CCT showed the lowest mean in group I (H. pylori negative group) in comparison to both groups II and III (both groups are $\mathrm{H}$. pylori positive) with statistically significant difference
( $\mathrm{P}<0.001)$ (table 1). While for comparing psychometric tests scores among the groups after treatment and after two months of 1 st evaluation, in our study, we found that CCT was significantly reduced in treated and eradicated group after therapy and showed statistically significant difference $(\mathrm{P}<0.001)$ in comparison with treated and failed to eradicate group as well as untreated group (table 2). Although NCT showed the lowest reduction following treatment in treated and eradicated group and in comparing results of psychometric tests before and after treatment in the same group showed a significant reduction but there was no statistically significant difference in comparison to the reduction in other studied groups.

Our study revealed that blood ammonia level among different groups before treatment showed statistically significant difference in group I $(\mathrm{H}$. pylori negative) $(65 \pm 17.47 \mu \mathrm{mol} / \mathrm{L})$ in comparison to group II and III (H.pylori positive) $(78.1 \pm 9.36 \mu \mathrm{mol} / \mathrm{L}$ and $82.73 \pm 12.22 \mu \mathrm{mol} / \mathrm{L}$ respectively) with $\mathrm{P}<0.001$ (table 3). while the blood ammonia level after treatment and 2 months from onset of the study was most reduced in group IIa (infected treated and successfully eradicated group) in comparison to group IIb (infected treated and failed to eradicate group) and III (infected control group) and this reduction was statistically significant $(\mathrm{P}<0.001)$ (table 4).

In our study, we found that comparing blood ammonia level pre- and post treatment showed highly significant reduction in treated and eradicated group $(\mathrm{P}<0.001)$ and it was also significant for those who were treated and failed to eradicate $(\mathrm{P}=0.023)$. While there was nonsignificant reduction regarding level of ammonia before and after 2 months of evaluation in infected control group who received no eradication treatment $(\mathrm{P}=0.14)$ (table 5).

Our study found a statistically significant difference in regard improvement of hepatic encephalopathy grade pre- and post treatment in $\mathrm{H}$ pylori-positive patients after treatment and successful eradication $(\mathrm{P}=0.04)$. While in other groups of H.pylori-positive who didn't receive eradication therapy or those who failed to eradicate, there was no statistically significant difference as regard to hepatic encephalopathy grade pre- and post treatment (table 6). 
Table (1): Psychometric tests scores among studied groups before treatment

\begin{tabular}{|l|c|c|c|c|c|}
\hline $\begin{array}{l}\text { Psycho-metric } \\
\text { test }\end{array}$ & $\begin{array}{c}\text { Group I } \\
\text { (uninfected } \\
\text { controls) } \\
\text { no=30 }\end{array}$ & $\begin{array}{c}\text { Group II } \\
\text { (infected } \\
\text { group) } \\
\text { no=30 }\end{array}$ & $\begin{array}{c}\text { Group III } \\
\text { (infected } \\
\text { controls) } \\
\text { no=30 }\end{array}$ & F & P \\
\hline $\begin{array}{l}\text { NCT } \\
\text { mean } \pm \text { SD } \\
(\text { range) }\end{array}$ & $\begin{array}{c}64.73 \pm 13.08^{*} \\
(44-94)\end{array}$ & $\begin{array}{c}77.2 \pm 9 \\
(56-95)\end{array}$ & $\begin{array}{c}78.03 \pm 12.42 \\
(56-102)\end{array}$ & 12.28 & $<0.001$ \\
\hline $\begin{array}{l}\text { CCT } \\
\text { mean } \pm \text { SD } \\
\text { (range) }\end{array}$ & $\begin{array}{c}35.67 \pm 6.66^{*} \\
(27-57)\end{array}$ & $\begin{array}{c}46 \pm 8.48 \\
(30-57)\end{array}$ & $\begin{array}{c}50.07 \pm 6.8 \\
(37-60)\end{array}$ & 30.53 & $<0.001$ \\
\hline
\end{tabular}

*significant difference from group II and III.

Table (2): Psychometric tests scores for group II (IIa: eradicated, IIb: failed to eradicate) and group III (infected controls) before and after treatment

\begin{tabular}{|c|c|c|c|c|c|}
\hline $\begin{array}{c}\text { Psycho-metric } \\
\text { test }\end{array}$ & $\begin{array}{c}\text { Group IIa (infected } \\
\text { \&eradicated) } \\
\text { no=24 }\end{array}$ & $\begin{array}{c}\text { Group IIb (failed } \\
\text { to eradicate) } \\
\text { no=6 }\end{array}$ & $\begin{array}{c}\text { Group III (infected } \\
\text { controls) } \\
\text { no }=\mathbf{3 0}\end{array}$ & $\bar{F}$ & $\overline{\mathbf{P}}$ \\
\hline $\begin{array}{l}1^{\text {st }} \mathrm{NCT} \\
\text { mean } \pm \text { SD } \\
(\text { range })\end{array}$ & $\begin{array}{c}76.75 \pm 9.51 \\
(56-95) \\
\end{array}$ & $\begin{array}{l}79 \pm 6.99 \\
(68-87) \\
\end{array}$ & $\begin{array}{c}78.03 \pm 12.42 \\
(56-102)\end{array}$ & 0.14 & 0.865 \\
\hline $\begin{array}{l}2^{\text {nd }} \mathrm{NCT} \\
\text { mean } \pm \text { SD } \\
\text { (range) }\end{array}$ & $\begin{array}{c}45.75 \pm 9.87 \\
(40-77)\end{array}$ & $\begin{array}{c}60.76 \pm 4.93 \\
(54-67)\end{array}$ & $\begin{array}{c}60.03 \pm 9.87 \\
(42-78)\end{array}$ & 2.3 & 0.109 \\
\hline $\mathbf{P}$ & $<0.001$ & 0.001 & $<0.001$ & & \\
\hline $\begin{array}{l}1^{\text {st }} \mathbf{C C T} \\
\text { mean } \pm \text { SD } \\
(\text { range })\end{array}$ & $45.25 \pm 8.85(30-57)$ & $\begin{array}{c}49 \pm 6.54 \\
(41-57)\end{array}$ & $\begin{array}{c}50.07 \pm 6.8 \\
(37-60)\end{array}$ & 2.68 & 0.77 \\
\hline $\begin{array}{l}2^{\text {nd }} \mathrm{CCT} \\
\text { mean } \pm \text { SD } \\
\text { (range) }\end{array}$ & $\begin{array}{c}30.46 \pm 4.9^{*} \\
(24-40\end{array}$ & $\begin{array}{c}38.67 \pm 2.8 \\
(35-42)\end{array}$ & $\begin{array}{c}37.07 \pm 5.48 \\
(27-46)\end{array}$ & 13.5 & $<0.001$ \\
\hline $\mathbf{P}$ & $<0.001$ & 0.006 & $<0.001$ & & \\
\hline
\end{tabular}

*significant difference from group IIb and III.

Table (3) blood ammonia level ( $\mathrm{mmol} / \mathrm{L}$ ) among different groups before treatment.

\begin{tabular}{|c|c|c|c|c|c|}
\hline & $\begin{array}{c}\text { Group I } \\
\text { (uninfected } \\
\text { controls) no=30 }\end{array}$ & $\begin{array}{c}\text { Group II } \\
\text { (infected group) } \\
\text { no=30 }\end{array}$ & $\begin{array}{c}\text { Group III } \\
\text { (infected controls) } \\
\text { no=30 }\end{array}$ & $\begin{array}{c}\text { Test of } \\
\text { significance } \\
\text { F }\end{array}$ & P \\
\hline $\begin{array}{c}\text { Mean } \\
\text { (range) }\end{array}$ & $65^{*}$ & 78.1 & 82.73 & 14.041 & $<0.001$ \\
\hline SSD & $170-104)$ & $(58-97)$ & $(65-104)$ & & \\
\hline
\end{tabular}

*significant difference from group II and III.

Table (4): Blood ammonia level (mmol/L) after treatment and 2 months of $1^{\text {st }}$ evaluation.

\begin{tabular}{|l|c|c|c|c|c|}
\hline & $\begin{array}{c}\text { Group IIa } \\
\text { (infected } \\
\text { \&eradicated) } \\
\text { no=24 }\end{array}$ & $\begin{array}{c}\text { Group IIb } \\
\text { (failed to } \\
\text { eradicate) } \\
\text { no=6 }\end{array}$ & $\begin{array}{c}\text { Group III } \\
\text { (infected } \\
\text { controls) } \\
\text { no=30 }\end{array}$ & $\begin{array}{c}\text { Test of } \\
\text { significance } \\
\text { F }\end{array}$ & P \\
\hline Mean & $49.04^{*}$ & $61.17 \#$ & 75 & 23.8 & $<0.001$ \\
(range) & $(13-73)$ & $(43-71)$ & $(44-104)$ & & \\
\hline ISD & 13.67 & 9.81 & 14.9 & & \\
\hline
\end{tabular}

*significant difference from group IIb and III.

\# significant difference from groupIII. 
Table (5): Blood ammonia level (mmol/L) pre- and post treatment between group II (IIa: eradicated, IIb: failed to eradicate), and group III (infected controls).

\begin{tabular}{|l|c|c|c|c|}
\hline \multicolumn{1}{|c|}{ Group } & $\begin{array}{c}\text { Pre-treatment } \\
\text { Mean } \pm \text { SD }\end{array}$ & $\begin{array}{c}\text { post-treatment } \\
\text { Mean } \pm \text { SD }\end{array}$ & t & P \\
\hline $\begin{array}{l}\text { Group IIa (infected \&eradicated) } \\
\text { no=24 }\end{array}$ & $79.21 \pm 9.1$ & $49.04 \pm 13.67$ & 9.97 & $<0.001$ \\
\hline $\begin{array}{l}\text { Group IIb (failed to eradicate) } \\
\text { no=6 }\end{array}$ & $73.67 \pm 9.89$ & $61.17 \pm 9.81$ & 3.25 & 0.023 \\
\hline $\begin{array}{l}\text { Group III (infected controls) } \\
\text { no=30 }\end{array}$ & $82.73 \pm 12.22$ & $\pm 14.9 \vee 0$ & 1.48 & 0.14 \\
\hline
\end{tabular}

Table (6): Changes of hepatic encephalopathy grade pre- and post treatment within each group (G.).

\begin{tabular}{|c|c|c|c|c|}
\hline Grade of HE & $\begin{array}{c}\text { Pre-treatment } \\
\text { no }(\%)\end{array}$ & $\begin{array}{c}\text { post-treatment } \\
\text { no }(\%)\end{array}$ & $\mathrm{Z}$ value & $\mathbf{P}$ \\
\hline Grade 0(G. IIa) & $3(12.5)$ & $9(37.5)$ & \multirow{3}{*}{2.05} & \multirow{3}{*}{0.04} \\
\hline Grade 1(G. IIa) & $13(54.16)$ & $11(45.83)$ & & \\
\hline Grade 2(G. IIa) & $8(33.33)$ & $4(16.66)$ & & \\
\hline Grade0(G. IIb) & $0(0.0)$ & $1(16.66)$ & \multirow{3}{*}{1.34} & \multirow{3}{*}{0.18} \\
\hline Grade1(G. IIb) & $3(50.00)$ & $4(66.66)$ & & \\
\hline Grade2(G. IIb) & $3(50.00)$ & $1(16.66)$ & & \\
\hline Grade 0(G. III) & $10(33.33)$ & $8(26.66)$ & \multirow{3}{*}{0.33} & \multirow{3}{*}{0.96} \\
\hline Grade 1(G. III) & $6(20.00)$ & $9(30.00)$ & & \\
\hline Grade 2(G. III) & $14(46.66)$ & $13(43.33)$ & & \\
\hline
\end{tabular}

\section{DISCUSSION}

Although baseline predictors are useful tools in $\mathrm{HE}$, ammonia has been one of the most widely studied etiological factors in the pathogenesis of hepatic encephalopathy. About half of the ammonia produced in the intestine is synthesized by luminal bacteria, with the remainder coming from dietary protein and glutamine [12]. Most currently available therapies for prevention of $\mathrm{HE}$ focus on reducing blood ammonia concentration $[13,14]$. $\mathrm{H}$ pylori is known to produce copious amounts of ammonia due to its strong urease activity [15]. The Hypothesis that $\mathrm{H}$. pylori are a significant risk factor for $\mathrm{HE}$ is still being debated, and the effectiveness of eradication therapy as treatment in $\mathrm{Hp}+$ patients remains controversial. Although studies continue to be published on the subject, the results are still inconclusive $[7,16]$. Previous studies have shown that ammonia levels in gastric juice were higher in patients with liver cirrhosis who had $\mathrm{H}$. pylori infection than in those who did not have such infection [17]. Infection with these bacteria has also been shown to be associated with elevation of blood ammonia levels and recurrent attacks of overt encephalopathy [18]. However, some other studies have failed to find a significant difference between fasting venous blood ammonia concentrations in patients with $\mathrm{H}$. pylori infection and those without [19].

The present study aimed to answer the most clinically relevant question of whether eradication therapy would improve the outcome of $\mathrm{HE}$ in cirrhotic patients who most commonly present to our clinical practice. Namely ambulatory patients, who present with mild to moderate grades of encephalopathy (Grade 0-2), In the present work, 90 educated patients with grade 0-II hepatic encephalopathy diagnosed using psychometric tests (NCT and CCT) and grading of the symptoms of hepatic encephalopathy is performed according to the West Haven classification system [11]. They were grouped depending on diagnosis of helicobacter pylori antigen in stool into 3 groups: non infected group (H. pylori negative), infected group who received treatment for $\mathrm{H}$. pylori eradication and infected group who didn't receive eradication therapy. Eradication rate in the group received eradication therapy was $80 \%$ (24/30). After treatment the comparison included the treated and successfully eradicated group, those who received eradication therapy but failed to eradicate and the infected group whom didn't receive eradication therapy. 
We did not find a significant difference in age, sex, liver impairment, Child-Pugh class, hepatic encephalopathy grade and precipitating factors of $\mathrm{HE}$ between $\mathrm{H}$ pylori-positive and -negative groups

We found that the time needed to perform NCT and CCT show the lowest mean in group I $(\mathrm{H}$. pylori negative group) in comparison to both groups II and III (both groups are H. pylori positive) with statistically significant difference $(\mathrm{P}<0.001)$. While for comparing psychometric tests scores among the groups after treatment (after two months of 1st evaluation), in our study, we found that CCT was significantly reduced in treated and eradicated group after therapy and showed statistically significant difference $(\mathrm{P}<0.001)$ in comparison with treated and failed to eradicate group as well as untreated group. Although NCT showed the lowest reduction following treatment in treated and eradicated group and in comparing results of psychometric tests before and after treatment in the same group showed a significant reduction but there was no statistically significant difference in comparison to the reduction agreement with results of a study conducted by Agrawal et al. in 2011, the changes in psychometric tests in patients with $\mathrm{HE}$ after treatment showed a significant reduction in the time taken to complete the psychometric tests after anti-H. pylori treatment [20]. While in another study by Demirturk et al. in 2001 who studied effect of $\mathrm{H}$. pylori eradication on visual evoked potentials (VEP) in cirrhotic patients, VEP recordings were abnormal in 14 out of 24 patients before the treatment. Only four of these 14 patients with abnormal recordings showed improvement which was statistically non significant $(\mathrm{P}>0.05)$ [21]. Also Rekha et al in 2007 , did not show any statistically significant difference between the patients with and those without $\mathrm{H}$. pylori infection regarding NCT[22].

Our study revealed that blood ammonia level among different groups before treatment showed statistically significant difference in group I $(\mathrm{H}$. pylori negative) in comparison to group II and III (H.pylori positive) with $\mathrm{P}<0.001$. These results agreed with studies which reached the same conclusion in regard to blood ammonia level where $\mathrm{H}$ pylori-positive patients' results were significantly higher than that in $\mathrm{H}$ pylorinegative patients $[6,23]$. While other studies' results came in contradiction with our results as there was no statistically significant difference between $\mathrm{H}$ pylori-positive and $\mathrm{H}$ pylori-negative patients[9, 24].

In the current study we found that, the blood ammonia level after treatment (2 months from onset of the study) was most reduced in group IIa (infected treated and successfully eradicated group) in comparison to group IIb (infected treated and failed to eradicate group) and III (infected control group) and this reduction was statistically significant $(\mathrm{P}<0.001)$. This came in agreement with other studies that found reduced ammonia concentration and recovery from HE after eradication $H$. pylori[6,21,25]. All of these studies are contrary to the results of Hassan et al. in 2007, where comparison of the eradication therapy among the $\mathrm{H}$ pylori-positive patients and antimicrobial therapy among $\mathrm{H}$ pylori-negative patients did not show any significant difference in the outcomes[24]. Also Miquel et al. in 2004 found that fasting blood levels of ammonia were comparable in $\mathrm{H}$. pylori infected and noninfected patients with advanced cirrhosis of the liver and sub clinical HE, and no reduction was observed after $\mathrm{H}$. pylori eradication among infected patients [9].

In our study, we found that comparing blood ammonia level pre- and post treatment within each group showed highly significant reduction in treated and eradicated group $(\mathrm{P}<0.001)$ and it was also significant for those who were treated and failed to eradicate $(\mathrm{P}=0.023)$. While there was non-significant reduction regarding level of ammonia before and after 2 months of 1 st evaluation in infected control group who received no eradication treatment $(\mathrm{P}=0.14)$. The reduction in blood ammonia in the treated and failed to eradicate group may be explained by inhibition of the intestinal flora with anti-H. pylori drugs or due to partial reduction of H.pylori bacterial load. However, our finding of a greater and significant improvement in blood ammonia levels in patients with $\mathrm{H}$. pylori infection who have successfully eradicated in comparison to those who were treated and failed to eradicate appears to indicate that $\mathrm{H}$. pylori infection contributed to high blood ammonia production in these patients and its eradication causes significant reduction of blood ammonia level. These results came in agreement with Agrawal et al. in 2011 who found a significant reduction in blood ammonia levels in both $\mathrm{H}$. pylori-positive and $\mathrm{H}$. pylori negative patients with $\mathrm{HE}$ after triple-drug anti-H. pylori treatment 
for one week. This reduction was more marked in patients with $\mathrm{H}$. pylori infection [20].

Our study found a statistically significant difference in regard improvement of hepatic encephalopathy grade pre- and post treatment in $\mathrm{H}$ pylori-positive patients after treatment and successful eradication $(\mathrm{P}=0.04)$. While in other groups of H.pylori-positive who didn't receive eradication therapy or those who failed to eradicate, there was no statistically significant difference as regard to hepatic encephalopathy grade pre- and post treatment. These results suggested significant clinical improvement in the infected and successfully eradicated group. These results agreed with results of Chen et al. in 2008 and Agrawal et al. in 2011 where HE rate significantly dropped after $\mathrm{H}$ pylori eradiation $[6,20]$. While results of Hassan et al. study conducted in 2007 showed that the score, grades and success rate of HE didn't significantly differ between those who received eradication therapy and those who received antimicrobial therapy alone [24].

In conclusion, data from our study suggested that H.pylori infection might augment the blood ammonia levels which may be additive risk for $\mathrm{HE}$ in patients with liver cirrhosis, and that eradication of this infection may help ameliorate the manifestations of this complication. Also it concluded that triple therapy in addition to its anti-H.pylori effect might has local GIT and systemic anti-bacterial effect on other bacteria, hence reduce the deterioration of liver status.

Funding: Non .

Conflicts of interest: Non .

Ethical approval: The protocol of the study was approved by the ethical committee of Faculty of Medicine, Zagazig University. Informed consents were obtained from all patients.

\section{REFERENCES}

1. Riggio O, Efrati C, Catalano C, Pediconi F, Mecarelli O, Accornero N, et al. High prevalence of spontaneous portal-systemic shunts in persistent hepatic encephalopathy: a case-control study. Hepatology 2005; 42(5):1158-65.

2. DuBois S, Eng S, Bhattacharya R, Rulyak S, Hubbard T, Putnam D, et al. Breath ammonia testing for diagnosis of hepatic encephalopathy. Dig Dis Sci 2005; 50: 1780-1784.

3. Liddel, HG and Scott, R. A lexicon: Abridged from Liddel and Scott's Greek-English Lexicon.Oxford (Oxfordshire) Oxford University Press.1996.
4. Smoot, D. T. How does Helicobacter pylori cause mucosal damage? Direct Mechanisms. Gastroenterology 1997; 113 (6 supl.) S31 - 41 discussion S50.

5. Dasani BM, Sigal SH, and Lieber CS. Analysis of risk factors for chronic hepatic encephalopathy: the role of Helicobacter pylori infection. Am J Gastroenterol,1998; 93: 726-31.

6. Chen SJ, Wang LJ, Zhu Q, Cai JT, Chen T, and $\mathrm{Si}$ JM. Effect of $\mathrm{H}$ pylri infection and its eradication on hyperammonemia and hepatic encephalopathy in cirrhotic patients. World $\mathbf{J}$ Gastroenterol 2008; 14(13): 1914-1918.

7. Calvet X, Nogueras C, Roque M, and Sanfeliu I. Helicobacter pylori is not a risk factor for hepatic encephalopathy. Dig Liver Dis 2001; 33: 414419.

8. Huber M, Rossle M, Siegerstetter V, Ochs A, Haag K, Kist M, et al. Helicobacter pylori infection does not correlate with plasma ammonia concentration and hepatic encephalopathy in patients with cirrhosis. Hepatogastroenterology 2001; 48: 541-544.

9. Miquel J, Barcena R, Boixeda D, Fernandez J, SanRoman AL, Martin-de-Argila C, et al. Role of Helicobacter pylori infection and its eradication in patients with subclinical hepatic encephalopathy._Eur J Gastroenterol Hepatol 2001; 13:1067-72.

10. Zullo A, Sanchez-Mete L, Hassan C, Diana F, Festuccia F, Attili AF, et al. Helicobacter pylori density and cagA status in cirrhotic patients: a case-control study. J Gastroenterol Hepatol 2004; 19: 1174-1178.

11. Atterbury CE, Maddrey WC,and Conn HO. Neomycin-sorbitol and lactulose in the treatment of acute portal-systemic encephalopathy. A controlled, double-blind clinical trial. Am J Dig Dis 1978 ;23:398-406.

12. Mousseau DD, and Butterworth RF. Current theories on the pathogenesis of hepatic encephalopathy. Proc Soc Exp Biol Med 1994; 206:329-44.

13. Romero-Gomez M, Grande L, Camacho I, Benitez S, Irles. JA, Castro M. Altered response to oral glutamine challenge as prognostic factor for overt episodes in patients with minimal hepatic encephalopathy. J Hepatol 2002; 37: 781787.

14. Nam YJ, Kim SJ, Shin WC, Lee JH, Choi WC, Kim KY et al. Gastric pH and Helicobacter pylori infection in patients with liver cirrhosis. Korean $J$ Hepatol 2004; 10: 216-222.

15. Miyaji H, Ito S, Azuma T, Yamazaki Y, Ohtaki $\mathrm{Y}$, Sato F, et al. Effects of Helicobacter pylori eradication therapy on hyperammonaemia in patients with liver cirrhosis. Gut 1997; 40: 726730.

16. Zullo A, Hassan C,and Morini S. Hepatic encephalopathy and Helicobacter pylori: a critical 
reappraisal. J Clin Gastroenterol 2001; 37: 164168.

17. Rilandi V, Zullo A, Diana F, and Capocaccia L.. Helicobacter pylori, Hyperammonemia and hepatic encephalopathy: is there a correlation? Am J Gastroenterol 1997;92: 723-34.

18. Gubbins GP, Moritz TE, Marsano LS, Talwalkar R., McClain C. J. and Mendenhall C. L. The Veterans Administration Cooperative Study Group No. 275. Helicobacter pylori is a risk factor for hepatic encephalopathy in acute alcoholic hepatitis: The ammonia hypothesis revised. Am J Gastroenterol. 1993;88: 1907-9.

19. Vásconez C, Elizalde JI, Llach J, Ginès A, de la Rosa C, Fernández RM. et al. Helicobacter pylori hyperammonemia and subclinical portosystemic encephalopathy: Effects of eradication. J Hepatol 1999;30: 260-4.

20. Agrawal A., Gupta A., and Chandra M. Role of Helicobacter pylori infection in the pathogenesis of minimal hepatic encephalopathy and effect of its eradication. Indian J Gastroenterol 2011; 30(1):29-32.

21. Demirturk L, Yazgan Y, Zci O, Ozel M, Togrol E, Gultepe $\mathrm{M}$ et al. The effect of Helicobacter pylori eradication on gastric juice and blood ammonia concentrations and on visual evoked potentials in cirrhotics. Helicobacter 2001; 6: 325-30.

22. Rekha C., Srinivasa M., Vidya A., A. Revathi and W. A. Asra. Role of Helicobacter Pylori and hyperammonemia in subclinical hepatic encephalopathy in cirrhosis of liver. Indian Journal of Clinical Biochemistry 2007; 22 (2) 136-139.

23. Si J, Cao Q, Gao M, Fang L, Qian G, Wang Y. Changes in serum ammonia concentration in cirrhotic patients with Helicobacter pylori infection. Chinese Medical Journal 2001; 113(12): 1080-1081.

24. Hassan A.H., Osama A., Serwah A.H., AbdelHamid A.S., and Hassan A.A. Effect of tripla therapy for helicobacter pylori eradication on hepatic encephalopathy; a randomized controlled trial. Egypt J. Neurol. Psychiat. Neurosurg 2007 ; 44(2): 623-634.

25. Ito S, Miyaji H, Azuma T, Yamazaki Y, Ohtaki $\mathrm{Y}$, Sato $\mathrm{F}$ et al. Hyperammonaemia and Helicobacter pylori. Lancet 1995;346:124-125. 